\title{
ДЕЙСТВИЕ СИСТЕМ ЗЕМЛЕДЕЛИЯ НА ВИДОВОЙ СОСТАВ СОРНЫХ РАСТЕНИЙ И УРОЖАЙНОСТЬ ЯЧМЕНЯ
}

\author{
Е.В. Носкова (фото) \\ к.с.-Х.н., агроном-исследователь научно-исследовательской \\ лаборатории ресурсосберегающих технологий \\ С.В. Щукин \\ к.С.-Х.Н., доцент, доцент кафедры агрономии \\ Т.П. Сабирова \\ к.с.-х.н., доцент, доцент кафедры агрономии \\ ФГБОУ ВО Ярославская ГСХА, г. Ярославль
}

Ячмень возделывают в основном как зернофуражную культуру, которая хорошо использует последействие удобрений, внесённых под предшественник [1]. В Ярославской области используют раз-

Система земледелия, органические удобрения, минеральные удобрения, сорные растения, ячмень, урожайность

Farming system, organic fertilizers, mineral fertilizers, weedage, barley, yield личные системы основной обработки почвы, но предпочтение в последние годы отдают минимальным, которые экономически более целесообразны. Также оказывают влияние как на продуктивность возделываемых культур, так и на плодородие почвы различные приёмы биологизации земледелия [2, 3, 4]. Целью исследований было выявить оптимальную систему земледелия под данную культуру.

\section{Условия и методы исследований}

Экспериментальная работа проводилась на опытном поле Ярославского НИИЖК - филиала ФНЦ «ВИК им. В.Р. Вильямса», расположенном в поселке Михайловское Ярославского муниципального района Ярославской области.

Изучение действия разных по интенсивности систем земледелия на структуру сорного компонента агрофитоценоза и урожайность ячменя ярового сорта Московский 3 проводилось в полевом двухфакторном опыте.

Системы земледелия:

1. Контроль (К) - без удобрений и без пестицидов.

2. Органоминеральная (ОМ) - минеральные удобрения $\mathrm{N}_{60} \mathrm{P}_{60} \mathrm{~K}_{90}$ органические удобрения - 60 т/га навоза после уборки ячменя под зяблевую вспашку.

3. Органоминеральная с пестицидами (ОМП) - агротехника и удобрения (как вариант 2), минеральные удобрения $\mathrm{N}_{60} \mathrm{P}_{60} \mathrm{~K}_{90}$ органические удобрения вносятся 1 раз за ротацию севооборота 60 т/га, после уборки ячменя и вспашки, защита растений от болезней, вредителей и сорняков.

4. Биологизированная (Б) - основана на биологических факторах с ограниченным применением минеральных удобрений $\left(\mathrm{N}_{30} \mathrm{P}_{30} \mathrm{~K}_{45}\right)$. Основная роль принадлежит культурам семейства бобовых, сидератам и органическим удобрениям. 
5. Органическая (О) - без минеральных удобрений. В качестве органических удобрений используются сидераты (рожь, поукосно рапс) и последний укос многолетних трав.

Учёт сорных растений проводили по методике Б.А. Смирнова и В.И. Смирновой [5]. Для учёта многолетних сорных растений использовались рамки $1 \mathrm{M}^{2}(1 \mathrm{M} \times 1 \mathrm{M})$, а для учёта малолетних видов $1 / 16$ м² $^{2}(0,25 \mathrm{~m} \times 0,25$ м). Учётные площадки выделяли методом рендомизации. Урожайность учитывалась сплошным поделяночным методом.

\section{Результаты исследований}

Вегетационный период 2017 года отличался дождливым и прохладным летом. Погодные условия были неблагоприятными для роста и развития культур. В сравнении с многолетними показателями отмечена повышенная норма выпавших осадков на протяжении всего вегетационного периода (в июле выпало в 1,5 раза больше).
В среднем за вегетацию на контроле в посевах ячменя встречалось 4 вида многолетних сорняков (табл. 1). Доля участия многолетних видов в структуре сообщества сорных растений составила $12,4 \%$. В посевах преобладал бодяк полевой $(10,5 \%)$.

Применение органоминеральных удобрений в полной дозе (OM), а также их с пестицидами (ОМП) способствовало снижению доли участия многолетних видов до 7,2\%. В посевах на данных вариантах встречалось 4 и 2 вида многолетников соответственно. На фоне с удобрениями без пестицидов (OM) преобладали такие виды, как осот полевой $(3,3 \%)$ и бодяк полевой $(2,2 \%)$. На фоне с удобрениями и пестицидами (ОМП) преобладали бодяк полевой $(4,7 \%)$ и осот полевой $(2,5 \%)$. Таким образом, на фонах с органоминеральными удобрениями в полной дозе происходит снижение доли участия многолетних видов сорных растений на 5,2\% по сравнению с контролем.

Таблица 1 - Видовой состав многолетних сорных растений в посевах ячменя

\begin{tabular}{|l|c|c|c|c|c|}
\hline \multirow{2}{*}{\multicolumn{1}{|c|}{ Вид растений }} & \multicolumn{5}{c|}{ Система земледелия } \\
\cline { 2 - 6 } & $\mathrm{K}$ & ОМ & ОМП & \multicolumn{2}{c|}{ Б } \\
\hline Всего, шт./м & 45,8 & 71,8 & 52,8 & 47,7 & 45,3 \\
\hline Всего многолетников, \% & 12,4 & 7,2 & 7,2 & 13,7 & 2,6 \\
\hline Бодяк полевой & 10,5 & 2,2 & 4,7 & 0,2 & 1,1 \\
\hline Одуванчик лекарственный & 0 & 0 & 0 & 0,4 & 0 \\
\hline Осот полевой & 0,4 & 3,3 & 2,5 & 0,8 & 1,5 \\
\hline Хвощ полевой & 0 & 0,5 & 0 & 0,5 & 0 \\
\hline Чистец болотный & 1,1 & 0 & 0 & 2,3 & 0 \\
\hline щавель курчавый & 0,4 & 1,2 & 0 & 0,5 & 0 \\
\hline
\end{tabular}

Уменьшается доля участия бодяка полевого на $5,8-8,3 \%$, повышается доля участия осота полевого на $2,1-2,9 \%$.

Внесение органических удобрений (O) также содействовало снижению доли участия многолетников до 2,6\%. В посевах встречалось 2 вида, преобладали осот полевой $(1,5 \%)$ и бодяк полевой $(1,1 \%)$. На данном варианте происходит снижение доли участия бодяка полевого (на 9,4\%) и увеличение осота полевого (на 1,1\%) в сравнении с контролем.

Наибольшая доля участия в структуре сообщества многолетних видов сорных растений отмечалась по фону органоминеральных удобрений со сниженной дозой (Б) и составила $13,7 \%$. В посевах встречалось 6 видов многолетних сорня- ков. Преобладали такие виды, как бодяк полевой $(9,2 \%)$, осот полевой $(9,2 \%)$ и чистец болотный $(2,3 \%)$. Отмечалось увеличение доли участия чистеца болотного, хвоща полевого, осота полевого и одуванчика лекарственного, снижение - бодяка полевого.

В посевах ячменя видовой состав малолетних сорных растений был представлен 14 видами (табл. 2). Доля участия малолетних видов в структуре сообщества сорных растений на контроле составила $87,6 \%$. Видовой состав представлен 9 видами. Постоянно присутствовали такие виды, как марь белая (35,0\%), ромашка непахучая $(14,7 \%)$ и звездчатка средняя (8,7\%).

Наибольшая доля участия малолетних видов сорных растений отмечалась по органическому 
Таблица 2 - Видовой состав малолетних сорных растений в посевах ячменя

\begin{tabular}{|c|c|c|c|c|c|}
\hline \multirow{2}{*}{ Вид растений } & \multicolumn{5}{|c|}{ Система земледелия } \\
\hline & K & OM & ОМП & 5 & $\mathrm{O}$ \\
\hline Всего, шт./м² & 45,8 & 71,8 & 52,8 & 47,7 & 45,3 \\
\hline Всего малолетников, \% & 87,6 & 92,8 & 92,8 & 86,3 & 97,4 \\
\hline Горец вьюнковый & 5,9 & 7,4 & 0 & 11,1 & 11,7 \\
\hline Горец шероховатый & 5,9 & 11,1 & 0 & 14,0 & 14,8 \\
\hline Звездчатка средняя & 8,7 & 7,4 & 2,6 & 11,1 & 6,0 \\
\hline Дымянка аптечная & 5,9 & 7,4 & 2,6 & 0 & 8,8 \\
\hline Марь белая & 35,0 & 29,7 & 37,3 & 19,5 & 32,4 \\
\hline Мятлик однолетний & 0 & 0 & 0 & 0 & 6,0 \\
\hline Незабудка полевая & 0 & 0 & 2,6 & 0 & 2,9 \\
\hline Пастушья сумка & 0 & 1,8 & 0 & 0 & 0 \\
\hline Пикульник красивый & 0 & 0 & 5,2 & 2,7 & 0 \\
\hline Подмаренник цепкий & 2,8 & 1,8 & 2,6 & 0 & 8,8 \\
\hline Ромашка непахучая & 14,7 & 3,8 & 12,5 & 16,8 & 6,0 \\
\hline Торица полевая & 2,8 & 3,8 & 0 & 0 & 0 \\
\hline Ярутка полевая & 5,9 & 13,0 & 24,8 & 11,1 & 0 \\
\hline Яснотка & 0 & 5,6 & 2,6 & 0 & 0 \\
\hline
\end{tabular}

фону (О) и составила 97,4\%, а наименьшая - по биологизированному фону (Б) - 86,3\%. По всем фонам удобрений преобладала марь белая. Наибольшее число видов малолетников (11) отмечается на органоминеральном фоне с полной дозой удобрений (ОМ). На биологизированном фоне (Б) со сниженной дозой наблюдалось 7 видов малолетников. Хорошо отзывались на органическую систему земледелия такие виды, как горцы, дымянка аптечная, мятлик однолетний, незабудка полевая и подмаренник цепкий; на органоминеральную - горцы, дымянка аптечная, пастушья сумка обыкновенная, торица полевая, ярутка полевая и яснотка пурпуровая.

Урожайность зерна ячменя на контроле составила 11,2 ц/га (табл. 3). Наибольшая урожайность зерна ячменя отмечалась на фоне органо-

Таблица 3 - Урожайность зерна ячменя, ц/га

\begin{tabular}{|c|c|}
\hline Система земледелия & Урожайность, ц/га \\
\hline K & 11,2 \\
\hline ОМ & 31,9 \\
\hline ОМП & 31,0 \\
\hline Б & 25,1 \\
\hline O & 10,7 \\
\hline
\end{tabular}

минеральных удобрений без пестицидов и составила 31,9 ц/га [5]. Применение органоминеральных удобрений в сниженной дозе способствовало увеличению урожайности до 25,1 ц/га. Система земледелия с органическим удобрением не привела к повышению урожайности зерна ячменя. Наоборот, наблюдалось её снижение.

\section{Выводы}

Система органического земледелия в посевах ячменя способствовала уменьшению доли участия многолетних видов на 9,8\% в сравнении с контролем. В посевах наблюдалось 2 вида многолетних сорняков - осот полевой $(1,5 \%)$ и бодяк полевой $(1,1 \%)$. С использованием органической 
системы земледелия увеличивается доля участия осота полевого на 1,1\%, снижается доля участия бодяка полевого на 9,4\%.

Применение органоминеральных удобрений с полной дозой и их с пестицидами также привело к снижению доли участия многолетников на 5,2\% в сравнении с контролем. На данных фонах происходит снижение доли участия бодяка полевого (на 5,8-8,3\%) и чистеца болотного (на $1,1 \%)$, повышение доли участия осота полевого (на 2,1-2,9\%).

Применение органоминеральных удобрений с пониженной дозой, наоборот, содействовало увеличению доли участия многолетних видов сорных растений на 1,3\%.
Наибольшее число видов малолетних сорных растений (11 видов) отмечается при внесении органоминеральных удобрений с полной дозой. По всем системам земледелия преобладала марь белая. Хорошо отзывались на органическую систему земледелия такие виды, как горцы, дымянка аптечная, мятлик однолетний, незабудка полевая и подмаренник цепкий; на органоминеральную - горцы, дымянка аптечная, пастушья сумка обыкновенная, торица полевая, ярутка полевая и яснотка пурпуровая.

Урожайность зерна ячменя повышалась при внесении органоминеральных удобрений в полной дозе на 20,7 ц/га (на 184,8\%) в сравнении с контролем.

\section{Лumepamypa}

1. Соловиченко, В.Д. Продуктивность ячменя в зависимости от вида севооборота, способа обработки почвы и удобрений [Текст] / В.Д. Соловиченко, А.Н. Воронин, В.В. Никитин, Е.В. Навольнева // Земледелие. - 2017. - № 7. - С. 29-32.

2. Лукин, С.В. Биологизация земледелия в Белгородской области: итоги и перспективы [Текст] / С.В. Лукин // Достижения науки и техники АПК. - 2016. - Т. 30. - № 7. - С. 20-23.

3. Самаров, В.М. Смешанные посевы чечевицы с ячменем - выгодно [Текст] / В.М. Самаров, Е.В. Ганзеловский // Вестник Красноярского государственного аграрного университета. - 2015. - № 9. - С. $167-169$.

4. Павлюченко, А.У. Плодородие почвы и продуктивность ячменя под воздействием удобрений в кормовом севообороте / А.У. Павлюченко, О.В. Гриднева, Л.А. Пискарева // Земледелие. - 2014. - № 7. C. $18-20$.

5. Смирнов, Б.А. Методика учёта засорённости посевов в полевом опыте [Текст] / Б.А. Смирнов, В.И. Смирнова // Известия ТСХА. - 1976. - Вып. 224. - С. 4.

\section{References}

1. Solovichenko, V.D. Produktivnost' jachmenja v zavisimosti ot vida sevooborota, sposoba obrabotki pochvy i udobrenij [Tekst] / V.D. Solovichenko, A.N. Voronin, V.V. Nikitin, E.V. Navol'neva // Zemledelie. - 2017. № 7. - S. 29-32.

2. Lukin, S.V. Biologizacija zemledelija v Belgorodskoj oblasti: itogi i perspektivy [Tekst] / S.V. Lukin // Dostizhenija nauki i tehniki APK. - 2016. - T. 30. - № 7. - S. 20-23.

3. Samarov, V.M. Smeshannye posevy chechevicy s jachmenem - vygodno [Tekst] / V.M. Samarov, E.V. Ganzelovskij // Vestnik Krasnojarskogo gosudarstvennogo agrarnogo universiteta. - 2015. - № 9. - S. 167169.

4. Pavlyuchenko, A.U. Plodorodie pochvy i produktivnost' jachmenja pod vozdejstviem udobrenij v kormovom sevooborote / A.U. Pavlyuchenko, O.V. Gridneva, L.A. Piskareva // Zemledelie. - 2014. - № 7. S. 18-20.

5. Smirnov, B.A. Metodika uchjota zasorjonnosti posevov v polevom opyte [Tekst] / B.A. Smirnov, V.I. Smirnova // Izvestija TSHA. - 1976. - Vyp. 224. - S. 4. 